\title{
Selenium and Glutathione Peroxidase Levels in Premature Infants in a Low Selenium Community (Christchurch, New Zealand)
}

\author{
KARL B. SLUIS, BRIAN A. DARLOW, PETER M. GEORGE, \\ NINA MOGRIDGE, BARBARA A. DOLAMORE, AND CHRISTINE C. WINTERBOURN \\ Departments of Pathology and Paediatrics, Christchurch School of Medicine, Christchurch Hospital, \\ Christchurch, New Zealand
}

\begin{abstract}
By world standards, the selenium status of the adult population of Christchurch, New Zealand is low. To determine the status of infants undergoing neonatal intensive care, plasma and red cell selenium and glutathione peroxidase levels were measured in infants admitted to the regional neonatal unit. Plasma levels in all newborn infants were one third to one half those in adults. Premature infants had levels significantly lower than those in cord blood from term infants, but their levels were not different from those of term infants admitted to the unit. There were no differences between adult and infant red cell levels. The premature infants remaining in the neonatal unit showed dramatic decreases in plasma selenium and glutathione peroxidase with age, with many infants having selenium levels of $<0.13 \mu \mathrm{mol} / \mathrm{L}(10 \mu \mathrm{g} / \mathrm{L})$. Low levels were seen in infants fed orally as well as those on parenteral nutrition. Thus, the low selenium status of New Zealanders is associated with particularly low selenium levels in premature infants. Because these infants have a high risk for oxidative diseases such as bronchopulmonary dysplasia (chronic lung disease) and retinopathy of prematurity, the possibility that these conditions are more serious in the New Zealand population needs to be assessed and consideration given to dietary supplementation. (Pediatr Res 32: 189-194, 1992)
\end{abstract}

\section{Abbreviations}

BPD, bronchopulmonary dysplasia

TPN, total parenteral nutrition

VLBW, very low birth weight

Premature infants are vulnerable to conditions such as BPD and retinopathy of prematurity in which oxidative tissue injury is thought to play a role $(1,2)$. The body's natural defense against reactive oxygen species includes the enzymes superoxide dismutase, catalase, and glutathione peroxidase, as well as small molecules such as vitamin $E$, ascorbic acid, and vitamin A $(3,4)$. At least three distinct forms of glutathione peroxidase, with different localization and substrate specificities, require selenium for activity $(3,5,6)$. Selenium is also a constituent of iodothyronine deiodinase, which converts thyroxine (T4) to 3,5,3'-triiodothyronine (T3) (7), and of other proteins whose functions are not known (6).

Fetal lungs have little need for antioxidants until they are

Received January 2, 1992; accepted April 1, 1992.

Correspondence: Dr. C. C. Winterbourn, Department of Pathology, Christchurch School of Medicine, P.O. Box 4345, Christchurch, New Zealand.

Supported by grants from the Health Research Council of New Zealand and the Canterbury Medical Research Foundation. exposed to oxygen at birth, and their levels of antioxidant enzymes remain low until just before term (8). The lungs of premature infants therefore may be vulnerable to oxidant damage. Glutathione peroxidase levels are regulated not only by development but also, at least in adults, by selenium availability $(9,10)$. Low selenium levels in animals and humans are associated with low glutathione peroxidase activity $(9,11)$, and selenium-deficient animals have increased susceptibility to oxidative lung injury (12). Low blood selenium levels in premature infants have been documented and suggested as a potential risk factor for BPD (13-17).

Measurements made in the 1970 s to mid-1980s show that New Zealand adults, particularly in the South Island, have some of the lowest selenium levels in the world $(18,19)$. Average blood selenium is about one third of that in North America and less than in most European centers $(10,18,20)$. In more replete selenium areas, infant levels are less than levels in adults (2123). There are limited data suggesting that this is also true in New Zealand $(18,24)$, although no very young infants have been studied and no information is available for premature infants. Before investigating links with BPD, we measured the selenium status and the glutathione peroxidase status of infants admitted to the regional neonatal unit at Christchurch Women's Hospital and studied their relationships to the age of the infants.

\section{MATERIALS AND METHODS}

Subjects. Christchurch Women's Hospital houses the regional neonatal unit for an area with some 7000 births per year. Approximately 400 infants are admitted to the unit annually. Infants admitted over an 18-mo period from November 1988 were potential candidates for the study provided that their parents gave consent and there was sufficient blood available for analysis. All infants in the study were treated at all times in accordance with standard protocols in the neonatal unit. For comparison, cord blood samples from 30 term infants and blood samples from 108 Christchurch adults were also collected. The study received ethical approval from the Canterbury Area Health Board Ethics Committee.

Full details of the pregnancy, birth history, and neonatal course including period of time on TPN and transfusions of blood products were collected prospectively. TPN is commenced routinely in VLBW infants requiring ventilation from the 2 nd or 3rd day of life and in other infants who are unable to tolerate enteral feeding. Initially, $1 \mathrm{~g} / \mathrm{kg} / \mathrm{d}$ of Vaminolact (Kabi Vitrum, Baxter, New Zealand) containing 10-15\% dextrose is introduced, and on subsequent days Intralipid (Kabi Vitrum, Stockholm, Sweden) $1 \mathrm{~g} / \mathrm{kg} / \mathrm{d}$ is also given. The amino acid mixture and lipid are both increased as tolerated to a maximum of $3 \mathrm{~g} / \mathrm{kg} / \mathrm{d}$ (25). Supplementary trace elements (not including selenium) are given as Ped-El $4 \mathrm{~mL} / \mathrm{kg} / \mathrm{d}$ and fat- and water-soluble vitamins 
as MVI Paediatric (Armour Pharmaceutical Co., Tarrytown, NY). Infants are preferentially fed their own mother's breast milk, whereas those who are too sick to be fed usually receive small "nonnutritive" amounts of expressed breast milk (typically $0.5 \mathrm{~mL}$ every $4 \mathrm{~h}$ ) from an early stage (26). Enteral feeding is gradually introduced as tolerated, at first with either expressed milk or, when this is not available, standard infant formula. When full feeds are established, extra calories may be provided by human milk fortifier (Enfamil, Mead Johnson, Evansville, IN) or premature formula (Similac Preterm, Ross Laboratories, Columbus, $\mathrm{OH})$. The standard infant formulas used were predominantly Karitane (Douglas Pharmaceuticals, Auckland, New Zealand) and Similac (Abbot Laboratories, Lower Hutt, New Zealand), both of which are manufactured in New Zealand. The premature formula is imported from the United States as a reconstituted fluid.

Infants were grouped depending on whether or not they were predominantly fed by TPN. The infants in the TPN group received TPN within a week of blood collection and for a total period of at least half their lives. Data were also related to whether or not the infant received transfusions of blood or plasma. Three groups were considered: 1) no blood or plasma, 2) plasma in excess of $50 \%$ of total plasma volume up to the time when the blood sample was taken, and 3) blood (with or without plasma) in excess of $50 \%$ of total blood volume. Few infants who were transfused received less than this amount. Total blood volume was estimated as $85 \mathrm{~mL} / \mathrm{kg}$ for infants $>1000 \mathrm{~g}$ and $110 \mathrm{~mL} / \mathrm{kg}$ for those $<1000 \mathrm{~g}$.

Blood collection. Standard practice in the neonatal unit is to perform a full blood count daily on all infants undergoing intensive care (ventilation, parenteral nutrition, major surgery) and at least weekly on infants requiring less intensive therapy or who are simply growing until suitable for discharge. The hematology laboratory requires $1 \mathrm{~mL}$ of blood but generally uses somewhat less. Blood in excess of laboratory requirements was used for this study, and no blood samples were taken expressly for the study. Blood was collected in EDTA, red cells and plasma were separated, and the red cells were washed twice with $0.9 \%$ $\mathrm{NaCl}$ then lysed with an equal volume of distilled water. In many instances, insufficient sample was available from a single collection and it was necessary to pool red cells and plasma from several days. The longest period for pooling was $5 \mathrm{~d}$. Samples were stored at $-80^{\circ} \mathrm{C}$ until analyzed.

Analyses. Selenium was measured in red cells and plasma by graphite furnace atomic absorption spectroscopy using a Varian Spectra AA40 with Zeeman background correction. Glutathione peroxidase was measured with t-butyl hydroperoxide as substrate by a modification of the method of Paglia and Valentine (27) carried out on a Cobas Bio centrifugal analyzer (Roche Labs, Nutley, NJ). A unit of activity is defined as $1 \mu \mathrm{mol} \mathrm{NADPH}$ oxidized per min under our experimental conditions. Each run was standardized against a stored hemolysate, the absorbance change of which varied $<10 \%$ between runs. Selenium and glutathione peroxidase levels in the red cell lysates were related to $\mathrm{Hb}$, measured using the Drabkin method (28). Comparision of the data from the different population groups was made using paired $t$ tests. Variations with gestational age and birth weight were analyzed by linear regression to compute the coefficient of determination $\left(r^{2}\right)$ from which the correlation coefficient $(r)$ was determined. Curves were fitted to the relationships between age of the infant and the four indices of selenium status using linear or polynomial regression analysis.

Milk samples were obtained from volunteer mothers of infants in the neonatal unit when there was a surplus to the infant requirement. Samples $(4 \mathrm{~mL})$ were collected into sterile plastic containers either by hand expression or with a breast pump. Selenium analyses were performed on the breast milks, and the formulas (Similac and Similac Preterm) and TPN solutions fed to the infants. The samples were stored at $-20^{\circ} \mathrm{C}$ until sent to Ruakura Animal Health Laboratory for selenium analysis. Anal- yses were performed on acid digests by an automated fluorimetric method (29). The lower limit of detection was $3 \mu \mathrm{g} / \mathrm{L}$ and the coefficient of variation was $5-6 \%$.

\section{RESULTS}

Sufficient red blood cells and plasma were available from a total of 85 infants admitted to the neonatal unit. There were 38 females and 47 males. The mean birth weight was $1795 \mathrm{~g}( \pm$ SD $960 \mathrm{~g}$ ) and the range was 550 to $4620 \mathrm{~g}$. Thirty-five infants were VLBW (less than $1500 \mathrm{~g})$. The mean gestation was $32 \mathrm{wk}( \pm \mathrm{SD}$ $4 \mathrm{wk}$ ) and the range was 24 to $43 \mathrm{wk}$. There were 70 premature infants (gestation less than 37 completed wk). Cord blood samples were available from 30 term infants who underwent normal birth. Their mean birth weight was $3450 \mathrm{~g}$ ( \pm SD $570 \mathrm{~g}$ ), range $1620-4820 \mathrm{~g}$, and mean gestation was $39.2 \mathrm{wk}$ ( \pm SD $2.1 \mathrm{wk}$ ), range 37 to $42 \mathrm{wk}$.

Table 1 compares the blood selenium and glutathione peroxidase levels of newborn infants admitted to the neonatal unit (age $<7$ d) with levels in cord blood from term infants and in adult blood. There were no significant differences in red cell levels between any of the groups ( $p>0.05)$, apart from the slightly higher $(p<0.05)$ levels in the term infants. (This difference was primarily due to high red cell selenium and glutathione peroxidase in two term infants, and if these were excluded significance was lost.) Plasma levels of selenium and glutathione peroxidase were substantially lower in the infants and the cords than in adults $(p<0.001)$. Both selenium $(p<0.001)$ and glutathione peroxidase levels $(p<0.05)$ were significantly lower for premature infants than for cords. Term infants were significantly higher than premature infants in glutathione peroxidase $(p<0.05)$ but not different in selenium. Some of the premature infants received blood transfusions, which might have affected subsequent selenium levels. However, exclusion of these infants $(n=3)$ made little difference to any of the mean values in Table 1.

Analyses for cord blood and infants $<7 \mathrm{~d}$ old are plotted against gestational age in Figure $1 A-D$. Plasma selenium and glutathione peroxidase and red cell selenium all increased with gestation, but there was no increase in red cell glutathione peroxidase. Because there was a high correlation between gestational age and birth weight $(r=0.90)$, plots of the data against birth weight showed the same trends as in Figure 1, with similar correlation coefficients $(r=0.34,0.27,0.27$, and 0.01 for plasma selenium, plasma glutathione peroxidase, red cell selenium, and red cell glutathione peroxidase, respectively).

Figure $2 A-D$ shows the variation in blood selenium and glutathione peroxidase with time after birth for premature infants. There was a significant drop soon after birth in plasma levels of both. Red cell levels showed little change, probably reflecting their slower turnover. As shown in Figure 2, a number of infants received transfusions of plasma or blood. Neither transfusion made a discernible difference to the decreases in plasma levels with age (Fig. $2 A$ and $B$ ), and it was not possible to distinguish any effects on red cell levels (Fig. $2 C$ and $D$ ). Inadequate selenium intake through TPN could explain the decline after birth. However, although some of the infants with very low selenium and glutathione peroxidase in Figure 2 were fed parenterally, others were fed formula or expressed breast milk. All the infants who stayed longer than a month in the neonatal unit were VLBW (birth weight $<1500 \mathrm{~g}$ ). However, low selenium levels were not restricted to the $41 \%$ VLBW infants.

In this study, we did not set out to establish clinical correlations with low selenium levels. However, it is noteworthy that of the 12 infants with plasma selenium levels $<0.19 \mu \mathrm{mol} / \mathrm{L}(15 \mu \mathrm{g} / \mathrm{L})$ eight were still requiring oxygen at $28 \mathrm{~d}$ and of these six had $\mathrm{x}-$ ray evidence of BPD. Five infants had evidence of acute retinopathy of prematurity and five of subependymal or intraventricular hemorrhage.

Previous studies of New Zealand adults have shown good correlations between selenium and glutathione peroxidase and 
Table 1. Selenium and glutathione peroxidase (GPX) concentrations in plasma and red cells from newborn infants, adults, and cord blood*

\begin{tabular}{|c|c|c|c|c|c|c|}
\hline \multirow[b]{3}{*}{ Group } & \multicolumn{2}{|c|}{ Plasma } & \multicolumn{4}{|c|}{ Red cells } \\
\hline & \multirow[b]{2}{*}{ Selenium $(\mu \mathrm{mol} / \mathrm{L}) \dagger$} & \multirow[b]{2}{*}{ GPx $(U / L)$} & \multicolumn{2}{|c|}{ Selenium $\dagger$} & \multicolumn{2}{|l|}{ GPx } \\
\hline & & & $\mathrm{nmol} / \mathrm{g} \mathrm{Hb}$ & $\mu \mathrm{mol} / \mathrm{L} \ddagger$ & $\mathrm{U} / \mathrm{g} \mathrm{Hb}$ & $\mathrm{U} / \mathrm{L}+$ \\
\hline Adults & $\begin{array}{l}0.94 \pm 0.24(108) \\
{[74]}\end{array}$ & $150 \pm 35(108)$ & $\begin{array}{c}3.7 \pm 1.6(108) \\
{[0.29]}\end{array}$ & 1.10 & $8.3 \pm 1.9(108)$ & 2490 \\
\hline Cord blood & $\begin{array}{l}0.46 \pm 0.10(30) \\
{[36]}\end{array}$ & $92 \pm 24(23)$ & $\begin{array}{l}4.2 \pm 0.8(23) \\
{[0.33]}\end{array}$ & 1.25 & $8.0 \pm 1.5(23)$ & 2400 \\
\hline Term infants\| & $\begin{array}{l}0.32 \pm 0.06(10) \\
{[25]}\end{array}$ & $99 \pm 27(10)$ & $\begin{array}{c}4.9 \pm 1.3(12) \\
{[0.39]}\end{array}$ & 1.44 & $9.7 \pm 3.1(12)$ & 2910 \\
\hline Premature infants $\|$ & $\begin{array}{l}0.34 \pm 0.13(24) \\
{[27]}\end{array}$ & $79 \pm 21(17)$ & $\begin{array}{c}3.7 \pm 1.3(27) \\
{[0.29]}\end{array}$ & 1.22 & $7.6 \pm 1.8(21)$ & 2280 \\
\hline
\end{tabular}

* Results are means \pm SD with number of samples in parentheses. Comparisons between the different populations were made using paired $t$ tests, the results of which are described in the text.

$\dagger$ Selenium concentrations in square brackets are expressed as $\mu \mathrm{g} / \mathrm{L}$ (plasma) or $\mu \mathrm{g} / \mathrm{g} \mathrm{Hb}$ (red cells).

$\$$ Calculated assuming a red cell $\mathrm{Hb}$ concentration of $300 \mathrm{~g} / \mathrm{L}$.

$\S$ From term infants.

|| Blood samples were collected within $7 \mathrm{~d}$ of birth.

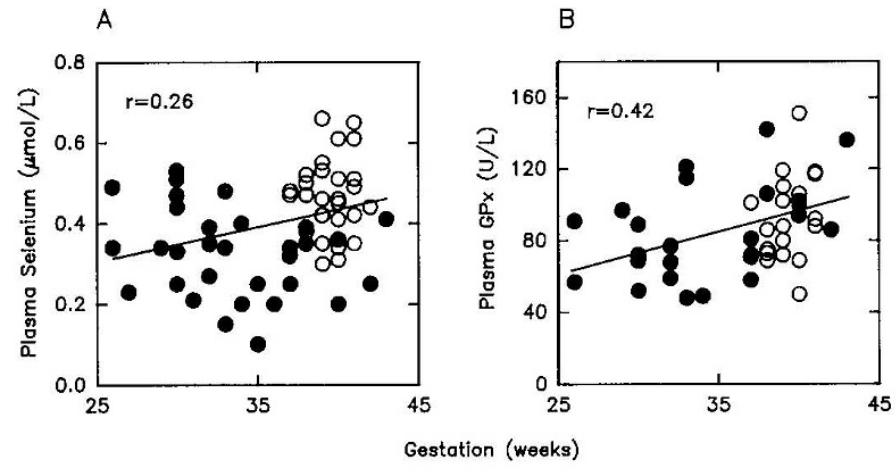

C

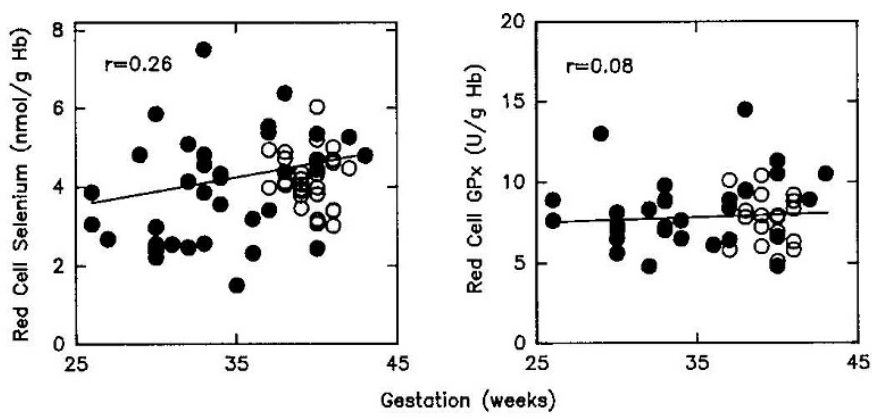

Fig. 1. Variations with gestational age. $A$, Plasma selenium; $B$, plasma glutathione peroxidase $(G P x) ; C$, red cell selenium; and $D$, red cell glutathione peroxidase. Data are for cord blood $(O)$ and infant blood collected within $7 \mathrm{~d}$ of birth (๑).

between red cell and plasma selenium $(9,10)$. Our adult results (Table 2) are consistent with this. For the premature infants, there was a good correlation between plasma selenium and glutathione peroxidase. However, there was no correlation between the red cell parameters, and relationships between plasma and red cells were weak or negative (Table 2).

Analyses carried out on 11 breast milk samples collected $23 \pm$ $11 \mathrm{~d}$ after parturition gave $19.8 \pm 5.8 \mu \mathrm{g}$ selenium/L. As expected for early milk (30), these values are higher than the mean of 13 $\mu \mathrm{g} / \mathrm{L}$ recently measured for mature milk samples (31). They are higher than previously reported for mature breast milk from the South Island of New Zealand (32), but reflect recently observed increases in adult blood selenium levels, which are possibly due to a greater consumption of imported wheat (George PM, Winterbourn CC, unpublished observation). The standard New Zealand infant formulas used (Similac and Karitane) both had selenium levels of $4.6 \mu \mathrm{g} / \mathrm{L}$, whereas the level in the Similac Preterm from the US was $11.8 \mu \mathrm{g} / \mathrm{L}$. The TPN solutions were below the detection limit of $3 \mu \mathrm{g} / \mathrm{L}$. The human milk fortifier contained $120 \mu \mathrm{g} / \mathrm{kg}$, so even with the maximum of $3 \mathrm{~g} / \mathrm{kg} / \mathrm{d}$ it contributed little to selenium intake. The daily selenium intake of the enterally fed infants, based on a daily milk intake of 180 $\mathrm{mL} / \mathrm{kg}$, should have ranged from $<1 \mu \mathrm{g} / \mathrm{kg}$ for infants receiving only standard formula to a maximum of 2.1 or $3.5 \mu \mathrm{g} / \mathrm{kg}$ for those receiving only preterm formula or breast milk, respectively. The selenium intake of infants on TPN would have been negligible.

\section{DISCUSSION}

Selenium is an essential constituent of various enzymes, including the glutathione peroxidases, which protect against oxidative injury. Infants are considered to be one of the highest risk groups for selenium deficiency (30). Previous studies in populations with higher selenium intakes than Christchurch have shown that newborn infants have substantially less plasma selenium and glutathione peroxidase than adults, but similar red cell levels $(14,22,33,34)$. Our results show the same trends but, because the selenium status of Christchurch adults is low, the red cell and plasma levels in each infant group are about half those reported for most other centers. We also found that plasma levels of selenium and glutathione peroxidase in newborn $(<7$-d-old) infants admitted to the neonatal unit were less than levels in cord blood. To some extent, this may represent decreases in the few days after birth, but the lower levels observed in premature infants are consistent with the trends that we observed with gestational age. Plasma selenium, glutathione peroxidase, and red cell selenium all showed positive correlations with gestational age or birth weight, which is consistent with an increase during perinatal development.

A problem in assessing selenium adequacy is to know the best parameter to measure (35). Glutathione peroxidase assays have the advantage of measuring a functional form. However, the units of activity depend on the conditions of the assay, so for comparison between laboratories, selenium levels are more useful. Changes in red cell levels depend on the rate of renewal of red cells in circulation. Thus, they respond slowly and give information on longer term selenium status. Plasma levels equilibrate within a few days, so they can respond quickly to any change in body stores $(9,35,36)$. Plasma measurements, there- 
A

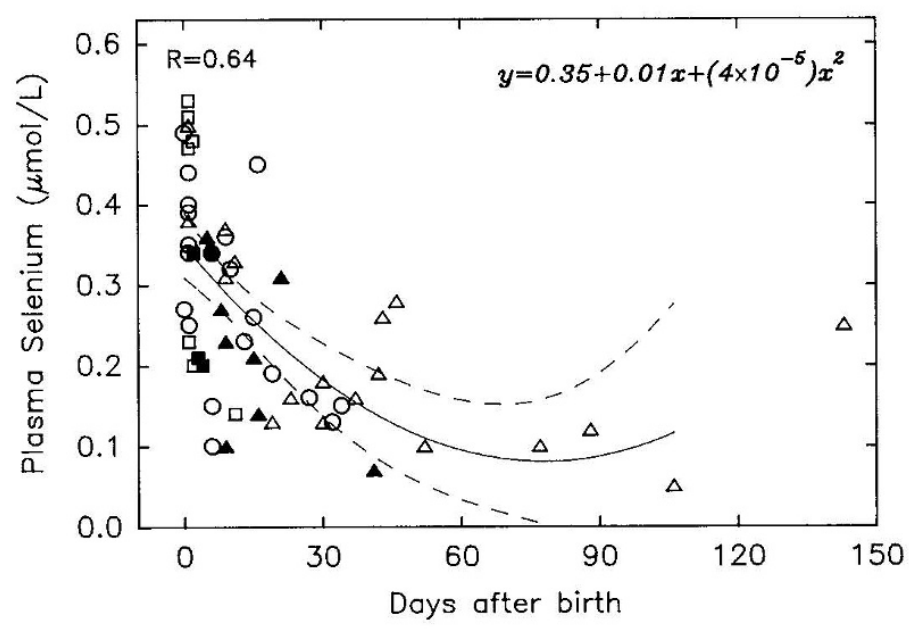

C

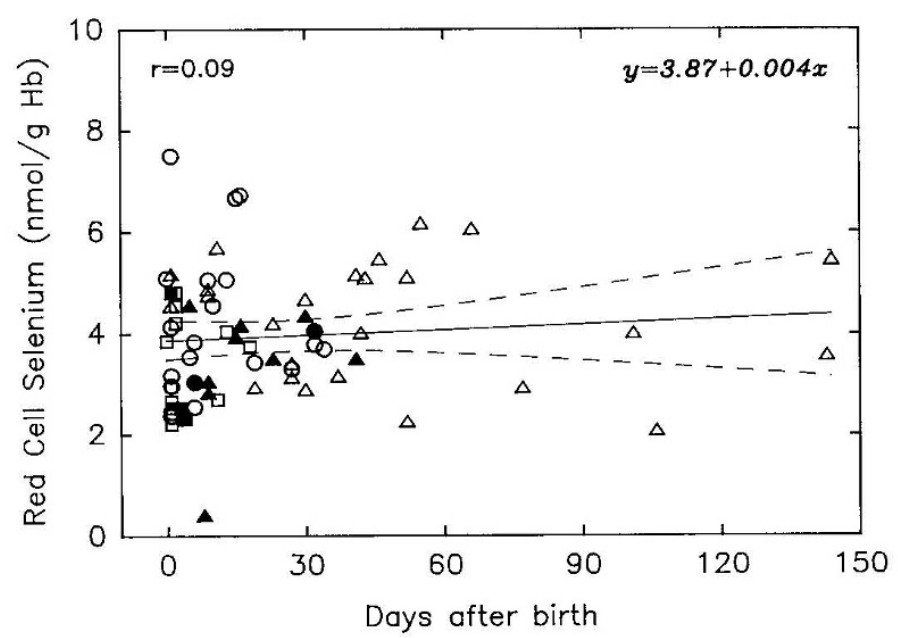

B
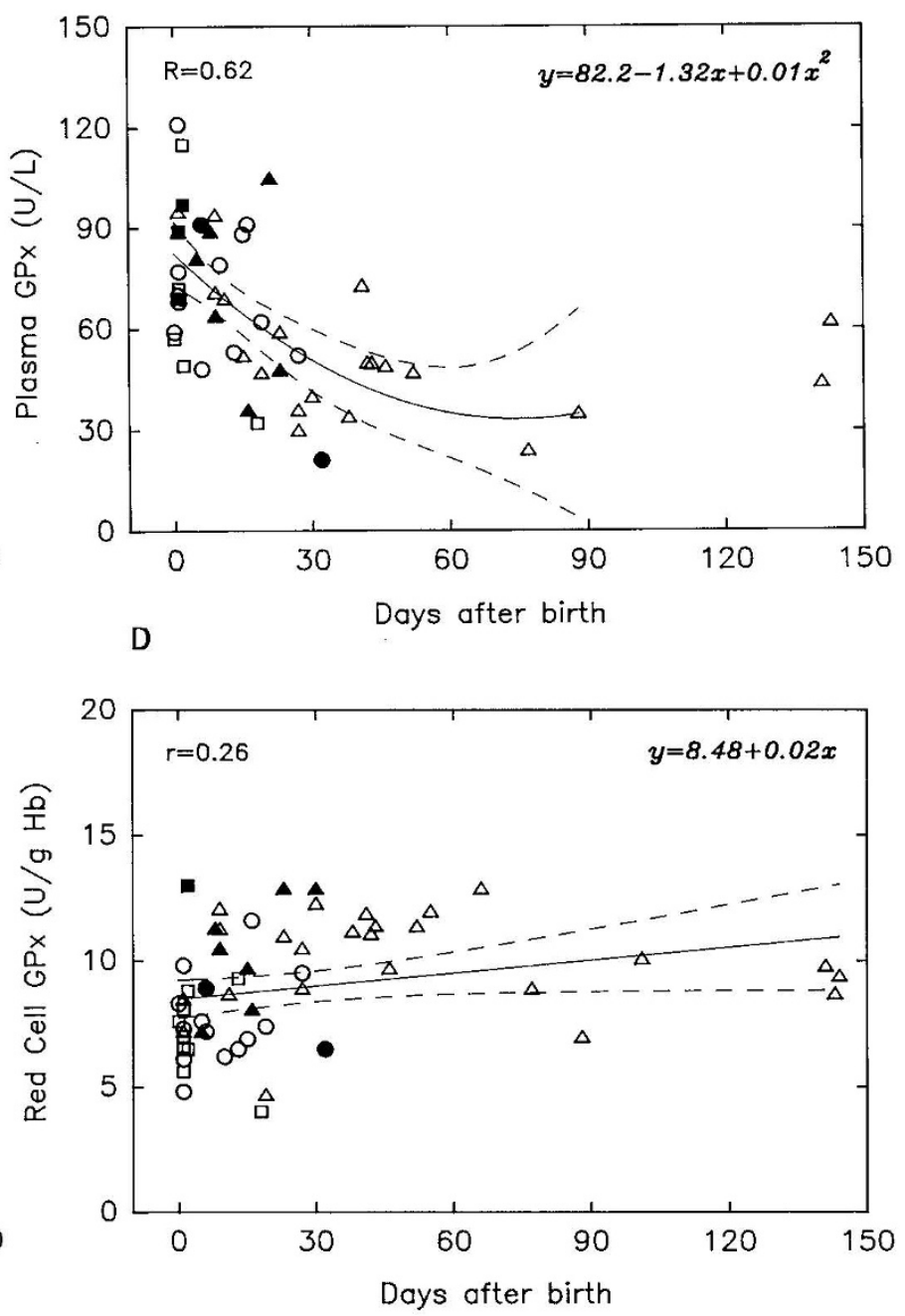

Fig. 2. Variations in selenium status with age for preterm infants. $A$, Plasma selenium; $B$, plasma glutathione peroxidase $(G P x)$; $C$, red cell selenium; $D$, red cell glutathione peroxidase. $O$, Infants who had received no blood or plasma; $\square$, cumulative plasma transfusion greater than $50 \%$ of plasma volume; $\triangle$, cumulative blood transfusion greater than $50 \%$ of blood volume before sample collection. Solid symbols represent infants who were primarily on parenteral nutrition. Regression lines (equations shown) are drawn as solid lines, with dashed lines representing $95 \%$ confidence intervals.

Table 2. Correlation coefficients between red cell and plasma selenium (Se) and glutathione peroxidase (GPx) levels in adults and preterm infants*

\begin{tabular}{ccc}
\hline & \multicolumn{2}{c}{ Correlation coefficient $(r) \dagger$} \\
\cline { 2 - 3 } & Adults & Preterm Infants \\
\hline Plasma Se $v s$ plasma GPx & 0.43 & 0.52 \\
& $(0.28,0.56)$ & $(0.10,0.94)$ \\
Red cell Se $v s$ red cell GPx & 0.60 & 0.00 \\
& $(0.48,0.70)$ & $(-0.40,0.40)$ \\
Plasma Se $v s$ red cell Se & 0.60 & 0.21 \\
& $(0.41,0.65)$ & $(0.14,0.51)$ \\
Plasma GPx $v s$ red cell GPx & 0.30 & -0.33 \\
& $(0.13,0.44)$ & $(-0.59,0.02)$ \\
\hline
\end{tabular}

* Data from ail infants but not cord blood are included.

$\dagger$ Values in parentheses are $95 \%$ confidence limits, calculated using Fisher's $Z$ transformation.

fore, should better reflect changes in status of infants undergoing rapid growth and development. We observed striking decreases in plasma selenium and glutathione peroxidase with age for premature infants remaining in the neonatal unit. Such changes were not apparent for red cells, probably because few infants were over 3 mo old and effects of red cell turnover were not apparent. However, our study of term infants up to $1 \mathrm{y}$ old showed that changes in red cells lag 2-3 mo behind changes in plasma (31). This suggests that red cell levels in the premature infants would eventually have fallen and that the limited changes in red cells did not reflect a stable selenium status.

Good correlations have been found between different parameters of selenium status in adults, until selenium becomes saturating $(9,10,35)$. The correlation between plasma selenium and glutathione peroxidase in our infants was reasonably strong, but relationships between plasma and red cells were much weaker. This is not surprising in view of the slower response rate of red cells and reinforces the desirability of measuring more than one index of selenium status.

Because Christchurch infants are already low in plasma selenium at birth, the subsequent drop in the premature infants results in extremely low levels of both selenium and glutathione peroxidase. The plasma values of $<0.13 \mu \mathrm{mol}(10 \mu \mathrm{g})$ selenium/ $\mathrm{L}$ are some of the lowest recorded in humans and are below the mean of $0.17 \mu \mathrm{mol} / \mathrm{L}$ reported for populations in which Keshan disease occurs (37). Studies of infants whose selenium intake was considered to be adequate showed gradual increases in blood 
levels after birth (22). A decline, therefore, does not appear to be physiologic. Measurements on Christchurch infants up to $1 \mathrm{y}$ old showed that red cell and plasma levels in breast-fed infants changed little from birth, but formula feeding was associated with rapid falls in plasma and more gradual falls in red cell levels (31). These changes reflected the low selenium levels in formula milks. The plasma selenium levels in many of the premature infants in this study were well below the mean of $0.25 \mu \mathrm{mol} / \mathrm{L}$ in the formula-fed infants. A decrease in plasma selenium has been observed previously for premature infants on TPN $(16,17$, 38,39 ). Because our infants were treated according to standard protocols, most received mixed diets and many had short periods of TPN. It is clear, however, that low plasma selenium status was not restricted to parenterally fed infants, implying that the selenium intake of infants fed both orally and by TPN was inadequate. Selenium was undetectable in the TPN solutions and low in the standard milk formulas used. Breast milk and the imported preterm formula were substantially higher in selenium, but it is apparently difficult to achieve sufficient intake from these sources. These results are consistent with those of Smith et al. (40). They found that, for premature infants with initial blood selenium levels more than double ours, higher selenium intake either from breast milk or from supplemented formula was not associated with higher blood selenium levels. They suggested that this reflects low selenium stores in premature infants and uptake into other compartments. In contrast to our study, they observed either no change or a slight drop in plasma selenium and glutathione peroxidase over a 3-wk period. The more dramatic decreases seen in our infants could reflect lower initial stores as well as a lower intake.

Premature infants often require blood or plasma transfusions. This could confound subsequent analyses, or provide an alternative source of selenium. The former did not appear to be a problem for plasma, where the half-life of selenium is short, because plasma levels of transfused infants appeared to be randomly distributed, and no major effect on red cell measurements was apparent. Because very low plasma levels were seen in spite of transfusion, blood does not appear to be a significant selenium source.

The dramatic decline in plasma selenium in premature infants, accompanied by a corresponding fall in glutathione peroxidase activity, leads to the question of whether their selenium intake is adequate or whether they should be given dietary supplementation. Lombeck et al. (41) observed no apparent ill effect attributable to plasma selenium levels $<0.25 \mu \mathrm{mol} / \mathrm{L}$ in childen with phenylketonuria or maple syrup urine disease. However, Lockitch et al. (16) considered that infants with a mean plasma selenium level of $0.25 \mu \mathrm{mol} / \mathrm{L}$ at $3 \mathrm{mo}$ could be at risk. Others $(14,17)$ have supplemented parentally fed infants with plasma selenium levels of less than 0.25 or $0.13 \mu \mathrm{mol} / \mathrm{L}$ and seen these levels to increase. All of our infants aged over $21 \mathrm{~d}$ were below the mean of Lockitch et al., some having scarcely detectable levels. If supplementation is needed, Christchurch infants should be prime candidates.

Before considering supplementation, the point at which low selenium status becomes a deficiency and the daily requirement for infants need to be defined $(42,43)$. Levander (44) estimates that older infants require a minimum of $10 \mu \mathrm{g} / \mathrm{d}$. Care must be taken because too much selenium is toxic, but with no reported cases of selenosis for infants receiving up to $47 \mu \mathrm{g} / \mathrm{d}$ there is a broad safety margin (44). There is less information available on the requirements for premature infants. Although a minimum intake of $1.5-2.5 \mu \mathrm{g} / \mathrm{kg} / \mathrm{d}$ has been recommended (45), our results and those of Smith et al. (40) suggest that this may not be adequate. A number of infants in our study had plasma and glutathione selenium peroxidase levels lower than those seen in Keshan disease. We have no direct evidence of adverse clinical outcomes such as cardiomyopathy among infants studied so far. However, such conditions as well as other less commonly reported associations with selenium deficiency such as muscle weakness (46) are not always easy to assess in sick, VLBW infants. Although international comparisons of neonatal chronic respiratory disorders are complicated by problems of definition of both the disease and the population denominator, it does appear that New Zealand may have a relatively high incidence of these conditions (47) and that the more selenium-deficient South Island has a higher incidence than the North Island. Because premature infants are at risk from diseases associated with oxidative stress, such as BPD, retinopathy of prematurity, and intraventricular hemorrhage, carefully executed trials of dietary supplementation for these infants must be favored. Information is first needed, however, on whether low selenium increases susceptibility, and our study is continuing to relate selenium status to indices of oxidative injury and clinical outcome for these diseases.

Acknowledgments. The authors thank S. Grant for assisting with the selenium analyses and Dr. J. E. Wells for statistical advice.

\section{REFERENCES}

1. Sinkin RA, Phelps DL 1987 New strategies for the prevention of bronchopulmonary dysplasia. Clin Perinatol 14:599-620

2. Phelps DL 1982 Neonatal oxygen toxicity: is it preventable? Pediatr Clin North Am 29:1233-1240

3. Sies H 1987 Antioxidant activity in cells and organs. Am Rev Respir Dis 136:478-480

4. Heffner JE, Repine JE 1989 Pulmonary strategies of antioxidant defense. Am Rev Respir Dis 140:531-554

5. Takahashi K, Cohen HJ 1986 Selenium dependent glutathione peroxidase protein and activity: immunological investigations on cellular and plasma enzymes. Blood 68:640-645

6. Burk RF 1990 Protection against free radical injury by selenoenzymes. Pharmacol Ther 45:383-385

7. Berry MJ, Banu L, Reed Larsen P 1991 Type I iodothyronine deiodinase is a selenocysteine-containing enzyme. Nature 349:438-439

8. Frank L, Sosenko IRS 1987 Development of lung antioxidant enzyme system in late gestation: possible implications for the prematurely born infant. $J$ Pediatr 110:9-14

9. Rea HM, Thomson CD, Campbell DR, Robinson MF 1979 Relation between erythrocyte selenium concentrations and glutathione peroxidase (EC 1.11.1.9) activities of New Zealand residents and visitors to New Zealand. Br J Nutr 42:201-208

10. Whanger PD, Beilstein MA, Thomson CD, Robinson MF, Howe M 1988 Blood selenium and glutathione peroxidase activity of populations in New Zealand, Oregon and South Dakota. FASEB J 2:2996-3002

11. Levander OA 1986 Selenium. In: Mertz W (ed) Trace Elements in Human and Animal Nutrition. Academic Press, Orlando, FL, pp 209-279

12. Cross CE, Hasegawa G, Reddy K, Omaye S 1977 Enhanced lung toxicity of oxygen in selenium-deficient rats. Res Commun Chem Pathol Pharmacol 16:695-706

13. Gross S 1976 Hemolytic anemia in premature infants: relationship to vitamin $\mathrm{E}$, selenium, glutathione peroxidase, and erythrocyte lipids. Semin Hematol 13:187-199

14. Pleban PA, Numerof B, Chrenka BA, Wirth F 1983 Monitoring trace element concentrations in blood from premature infants in a neonatal intensive care unit. In: Brown SS, Savory J (eds) Chemical Toxicity and Clinical Chemistry of Metals. Academic Press, New York, pp 343-346

15. Huston RK, Shearer TR, Jelen BJ, Whall PD, Reynolds JW 1987 Relationship of antioxidant enzymes to trace metals in premature infants. $J$ Parenteral Enteral Nutr 11:163-168

16. Lockitch G, Jacobson B, Quigley G, Dison P, Pendray M 1988 Selenium deficiency in low birth weight neonates: an unrecognized problem. J Pediatr 114:865-870

17. Amin S, Chen SY, Collip PJ, Castro-Magana M, Maddaiah VT, Klein SW 1980 Selenium in premature infants. Nutr Metab 24:331-340

18. Thomson CD, Robinson MF 1980 Selenium in human health and disease with emphasis on those aspects peculiar to New Zealand. Am J Clin Nutr 33:303323

19. Robinson MF 1989 Selenium in human nutrition in New Zealand. Nutr Rev 47:99-107

20. Thorling EB, Overvad K, Geboers J 1986 Selenium status in Europe-human data. A multicenter study. Ann Clin Res 18:3-7

21. Lombeck I, Kasperek K, Harbisch ND, Feinendegen LE, Bremer NJ 1977 The selenium state of healthy children. Eur J Pediatr 125:81-88

22. Kumpulainen J, Salmenpera L, Siimes MA, Koivistoinen P, Perheentupa J 1985 Selenium status of exclusively breast-fed infants as influenced by maternal organic or inorganic selenium supplementation. Am J Clin Nutr 42:829-835

23. Smith AM, Picciano MF, Milner JA 1982 Selenium intakes and status of human milk and formula fed infants. Am J Clin Nutr 35:521-526 
24. McKenzie RL, Rea HM, Thomson CD, Robinson MF 1978 Selenium concentration and glutathione peroxidase activity in blood of New Zealand infants and children. Am J Clin Nutr 31:1413-1418

25. American Academy of Pediatrics Committee on Nutrition 1985 Nutritional needs of low-birth-weight infants. Pediatrics 75:976-986

26. Lucas A 1986 Feeding low birthweight infants. In: Roberton NRC (ed) Textbook of Neonatology. Churchill Livingstone, Edinburgh, UK, pp 204-210

27. Jaskot RH, Charlet EG, Grose EC, Grady MA, Roycroft JH 1983 An automated analysis of glutathione peroxidase, $\mathrm{S}$-transferase, and reductase activity in animal tissue. $\mathrm{J}$ Anal Toxicol 7:86-88

28. Beutler E 1984 Red Cell Metabolism: A Manual of Biochemical Methods, 3rd Ed. Grune \& Stratton, Orlando, FL

29. Watkinson JH 1979 Semi-automated fluorimetric determination of nanogram quantities of selenium in biological material. Anal Chim Acta 105:319-325

30. Litov RE, Combs GF 1991 Selenium in pediatric nutrition. Pediatrics 87:339351

31. Dolamore BA, Brown J, Darlow BA, George PM, Sluis KB, Winterbourn CC 1992 Selenium status of Christchurch infants and the effect of diet. N Z Med J 105:139-142

32. Williams MMF 1983 Selenium and glutathione peroxidase in mature human milk. Proc Univ Otago Med Sch 61:20-21

33. Alfthan G 1986 Selenium status of nonpregnant, pregnant women and neonates. Acta Pharmacol Toxicol 59(suppl 7):142-145

34. Rudolph N, Wong SL 1978 Selenium and glutathione peroxidase activity in maternal and cord plasma and red cells. Pediatr Res 12:789-792

35. Levander OA 1985 Considerations on the assessment of selenium status. Fed Proc 44:2579-2583

36. Cohen NJ, Chovaniec ME, Mistretta D, Baker SS 1985 Selenium repletion and glutathione peroxidase differential effects on plasma and red blood cell enzyme activity. Am J Clin Nutr 41:735-747
37. Xia Y, Hill KE, Burk RF 1989 Biochemical studies of a selenium deficient population in China: measurement of selenium, glutathione peroxidase and other oxidant defense indices in blood. J Nutr 119:1318-1326

38. Van Caillie-Bertrand M, Degenhart HJ, Fernandes J 1984 Selenium status of infants on nutritional support. Acta Paediatr Scand 73:816-819

39. Nuston RK, Benda GI, Carlson CV, Shearer TR, Reynolds JW, Neerhout RC 1982 Selenium and vitamin E sufficiency in premature infants requiring total parenteral nutrition. J Parenteral Enteral Nutr 6:507-510

40. Smith AM, Chan GM, Moyer-Mileur LJ, Johnson CE, Gardner BR 1991 Selenium status of preterm infants fed human milk, preterm formula, or selenium-supplemented preterm formula. J Pediatr 119:429-433

41. Lombeck I, Kasperek K, Narbisch ND, Becker K, Schumann E, Schroter W, Feinendeger LE, Bremer NJ 1978 The selenium state of children II: selenium content of serum, whole blood, hair and the activity of erythrocyte glutathione peroxidase in dietetically treated patients with phenylketonuria and maple syrup urine disease. Eur J Pediatr 128:213-223

42. Milner JA 1990 Trace minerals in the nutrition of children. J Pediatr 117:S147S155

43. Kumpulainen J 1989 Selenium requirement and supplementation. Acta Paediatr Scand 351:114-117

44. Levander OA 1989 Upper limit of selenium in infant formulas. J Nutr 119:1869-1873

45. Casey CE, Nambidge KM 1985 Trace minerals. In: Tsang RC (ed) Vitamin and Mineral Requirements in Preterm Infants. Marcel Dekker, New York, pp $165-170$

46. van Rij AM, Thomson CD, McKenzie JM, Robinson MF 1979 Selenium deficiency in total parenteral nutrition. Am J Clin Nutr 32:2076-2085

47. Darlow BA, Norwood LJ 1992 Chronic lung disease in very low birthweight infants: a prospective population based study. J Paediatr Child Health (in press) 